\title{
Atherosclerotic Plaque
}

National Cancer Institute

\section{Source}

National Cancer Institute. Atherosclerotic Plaque. NCI Thesaurus. Code C78739.

Fatty tissue which is deposited in the inner lining of the arterial wall. 